\title{
Seasonal variations in leaf and branch trace elements and the influence of a 3 -yr $100 \%$ rainfall exclusion on Pinus massoniana Lamb
}

\author{
Tian Lin ${ }^{1,2}$, Xuanmei Zheng ${ }^{3}$, Huaizhou Zheng ${ }^{\text {Corresp. } 2}$ \\ ${ }^{1}$ Fujian University of Technology, School of Ecological Environment and Urban Construction, Fuzhou, Fujian, China \\ 2 Fujian Normal University, Fujian Provincial Key Laboratory for Plant Eco-physiology, Fuzhou, Fujian, China \\ ${ }^{3}$ Fujian Jiangxia University, Straits College of Finance and Economics, Fuzhou, Fujian, China \\ Corresponding Author: Huaizhou Zheng \\ Email address: zhz@fjnu.edu.cn
}

Background. Trace elements are essential for the growth and survival of plants, and their concentrations and distributions in plants are effective reflections of ecological adaptation strategies. However, this aspect has seldom been addressed.

Method. Changes in the leaf and branch trace elements of Pinus massoniana Lamb, induced by seasonal dynamics and in response to a $3-y r$ 100\% rainfall exclusion, were evaluated.

Results. The results showed that the concentrations of $\mathrm{Fe}, \mathrm{Cu}, \mathrm{Zn}, \mathrm{Cd}, \mathrm{Ni}$ and $\mathrm{Cr}$ in leaves of $P$. massoniana in the control group had high seasonal resolution. There were three groups according to their patterns over the growing season: (1) nutrient elements ( $\mathrm{Cu}, \mathrm{Zn}, \mathrm{Ni}$ and $\mathrm{Cr}$ ), which continuously decreased in concentration during the growing season, with the highest concentration in spring and the lowest in autumn; (2) accumulating element ( $\mathrm{Cr}$ ), which increased in concentration from spring to autumn; and (3) indifferent element (Fe), which increased in concentration from spring to summer and decreased in concentration from summer to autumn. The concentrations of trace elements in leaves and branches showed no significant differences with mild drought stress, except for $\mathrm{Fe}$ and $\mathrm{Cr}$ in leaves and $\mathrm{Cr}$ in branches, which significantly increased $(p<0.05)$ under the result of self-selection under mild drought stress. Therefore, the resultant seasonal and drought effects on trace element cycling in $P$. massoniana could provide theoretical support to respond to future climate change. 
1 Seasonal variations in leaf and branch trace elements

\section{and the influence of a $3-y r 100 \%$ rainfall exclusion on Pinus massoniana Lamb}

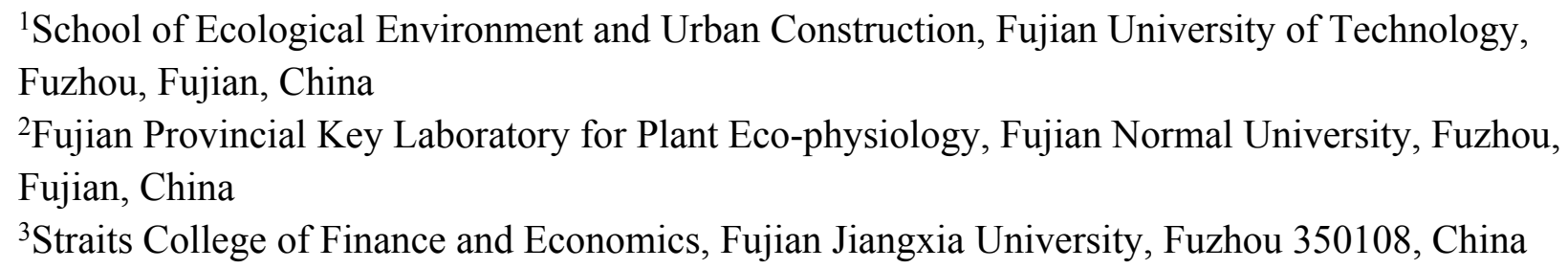

\section{Abstract}

Background. Trace elements are essential for the growth and survival of plants, and their concentrations and distributions in plants are effective reflections of ecological adaptation strategies. However, this aspect has seldom been addressed.

Method. Changes in the leaf and branch trace elements of Pinus massoniana Lamb, induced by seasonal dynamics and in response to a 3-yr 100\% rainfall exclusion, were evaluated.

Results. The results showed that the concentrations of $\mathrm{Fe}, \mathrm{Cu}, \mathrm{Zn}, \mathrm{Cd}, \mathrm{Ni}$ and $\mathrm{Cr}$ in leaves of $P$. massoniana in the control group had high seasonal resolution. There were three groups according to their patterns over the growing season: (1) nutrient elements $(\mathrm{Cu}, \mathrm{Zn}, \mathrm{Ni}$ and $\mathrm{Cr})$, which continuously decreased in concentration during the growing season, with the highest concentration in spring and the lowest in autumn; (2) accumulating element (Cr), which increased in concentration from spring to autumn; and (3) indifferent element (Fe), which increased in concentration from spring to summer and decreased in concentration from summer to autumn. The concentrations of trace elements in leaves and branches showed no significant differences with mild drought stress, except for $\mathrm{Fe}$ and $\mathrm{Cr}$ in leaves and $\mathrm{Cr}$ in branches, which significantly increased $(p<0.05)$ under the result of self-selection under mild drought stress. Therefore, the resultant seasonal and drought effects on trace element cycling in P. massoniana could provide theoretical support to respond to future climate change.

\section{Introduction}

As an important part of the terrestrial ecosystem, the forest ecosystem has the characteristics of strong stability and perfect function (Hisano et al. 2018). Trace elements, defined as elements that are present at low concentrations (mg.kg-1 or less) in most soils, plants and living organisms 
38

39

40

41

42

43

44

45

46

47

48

49

50

51

52

53

54

55

56

57

58

59

60

61

62

63

64

65

66

67

68

69

70

71

72

73

74

75

76

77

(Phipps 1981), are widely distributed in the forest ecosystem and essential for the growth and survival of plants. The contamination of terrestrial environments with trace elements is a common environmental stress phenomenon worldwide (Eid \& Shaltout 2014). Fe, Cu, Zn, Cd and other trace elements in forest plants come from the soil and atmosphere, and are elements that cannot be degraded by microbial or chemical processes to alter their toxicity. Long-term accumulation of trace elements causes chronic damage to living organisms; for example, increasing the concentration of trace elements in plants affects normal growth and physiological and ecological characteristics (Peñuelas 2002). Plants are sessile organisms that must cope with variable environments (Van Ieperen 2016), both in space and time, and this may induce changes in abiotic factors (light, temperature and water) and biotic factors (bacteria and fungi)(Etienne et al. 2018). For example, plants absorb heavy metals from the atmosphere and soil through respiration, and the root system potentially harbors hazards. To survive, grow and reproduce, plants must develop multiple physiological mechanisms to maintain a reasonable range of trace elements (Philippot et al. 2013). Many studies suggest that environmental fluctuations and features of the ecosystem (such as plant growth strategies, and soil nutrient heterogeneity) affect foliar nutrient elemental concentrations (Han et al. 2005; He et al. 2015; Kerkhoff et al. 2005; Sardans et al. 2011). Changes in the concentrations of nutrient elements during plant growth can reflect the physiological and growth characteristics of plants to a certain extent. In addition, trace elements are involved in all metabolic and cellular functions, have the ability to form stable compounds with biological organic macromolecules, and can remain in plant tissue for a long time and have seasonal effects (Baycu et al. 2006). Therefore, the study of seasonal variations in plant trace elements can be beneficial to further understanding of the nutrient status and growth trends of the plants.

Currently, most research on the characteristics of nutrient elements is mainly focused on the concentrations of C, N, P, K and other macro elements (Güsewell et al. 2005; Sardans et al. 2013; Urbina et al. 2015; Wang et al. 2013; Woods et al. 2003). Because of their roles in several physiological functions in plants, such elements correlate with the growth rate (Elser et al. 2010; Peñuelas et al. 2013; Sardans et al. 2013) and with the structure and function of plant communities (Elser et al. 2003; Sardans \& Peñuelas 2012). The C:N:P ratio in organisms can be associated with important ecological processes, such as responses to environmental stress (Sardans et al. 2013; Woods et al. 2003), and ecosystem composition and diversity (Güsewell et al. 2005; Roem \& Berendse 2000). However, trace elements that help macronutrients improve physiological functions are not well studied (Paiva et al. 2017; Sardans et al. 2007; Waraich EA 2011). Some studies of trace elements vary along environmental gradients (Eid \& Shaltout 2014; Paiva et al. 2017), and their resistance to stress (Mahdavi S 2016; Urbina et al. 2015). Water is the most limiting factor in ecosystems and regulates plant growth and yield; a lack of water leads to a substantial number of effects on plants and species relationships, including readjustment of transport and metabolic processes, community diversity and ecosystem productivity (Peñuelas et al. 2013). A drought-induced decrease in soil moisture content may reduce the rate at which plants absorb trace elements. If we are to fully understand the impact of climate change on 
ecosystems, it is necessary to study the interactions between predicted droughts and the changes in trace elements. However, it is uncertain whether and how drought can affect trace element dynamics.

The leaf is the main site of photosynthesis and the most active organ in plant metabolism, its chemical element concentrations can reflect plant absorption and accumulation of elements (Anderson \& Proctor 1990; Grubb et al. 2009), revealing the plant's demand for nutrient elements and adaptability and feedback to climate and regional changes. The branch is another important photosynthetic organ. when the leaf area is small or the leaves are degenerated, the branch adopts the role of leaves to perform physiological functions, such as photosynthesis and transpiration (Lacointe et al. 1993). Therefore, the concentrations of elements in branches will change with the environmental changes. Trace elements in leaves and branches show different physiological functions. For example, Fe plays an important role in regulating osmotic pressure, promoting protein synthesis, and improving photosynthetic capacity and plant resistance (Ahanger et al. 2016); $\mathrm{Zn}$ is a component of various enzymes in plants and is involved in plant respiration and carbohydrates transformation (Blasco et al. 2015; R Hajiboland 2012); and $\mathrm{Cu}$ plays a key role in photosynthetic and respiratory electron transport chains, ethylene sensing, cell wall metabolism, and protection from oxidative stress (Yruela 2009). Changes in environmental factors such as water and temperature have controversial effects on the accumulation of trace element. For example, some scholars believed that under drought conditions, the increased accumulation of trace elements can enhance the negative effects of drought on plant productivity; on the other hand, the decrease in trace element accumulation increases the productive capacity of these ecosystems and improves their capacity to resist drought (Sardans \& Peñuelas 2007). Other scholars have come to contrasting conclusions.

This study investigated changes in leaf and branch trace elements of $P$. massoniana induced by the annual seasons and in response to a 3-yr manipulated precipitation experiment (100\% rainfall exclusion) that began in April 2013 and ended in January 2016 in Changting County, Fujian Province, China. In this experiment, the local pioneer P. massoniana was taken as the research object to study the seasonal dynamic of the trace elements and the influence of drought on it, to provide theoretical support for the future response of forest species to climate change. Here, the concentrations of six selected trace elements ( $\mathrm{Fe}, \mathrm{Cu}, \mathrm{Zn}, \mathrm{Cd}, \mathrm{Ni}$, and $\mathrm{Cr}$ ) in the leaves and branches of P. massoniana growing in the control group (natural conditions) and the drought group (100\% rainfall exclusion) were determined. The present research was performed to investigate (1) the seasonal dynamics characteristics of leaf and branch trace element concentrations in P. massoniana over the study period; (2) whether drought increases or decreases trace element concentrations and accumulations in leaves and branches of $P$. massoniana; and (3) the interaction between trace element concentrations and seasonal variations or drought.

\section{Materials \& Methods}

\section{Research Area}


The sampling site was located in Hetian Town, Changting County, Western Fujian Province, China $\left(116^{\circ} 18^{\prime}-116^{\circ} 31^{\prime} \mathrm{E}, 2^{\circ} 33^{\prime}-25^{\circ} 48^{\prime} \mathrm{N}, 310\right.$ asl) (Figure 1). This site was one of the most serious red soil erosionsites in China. Because of soil depletion, the dominant species were $P$. massoniana, Schima superba, Castanopsis fargesii and Lithocarpus sp., and there were only a few Dicranopteris dichotoma (Thumb) Berhn under the forest. This area had a humid monsoon climate in the middle subtropical zone, with distinct dry and wet seasons. The rainfall was mainly concentrated from May to July every year, with an average annual rainfall of $1737 \mathrm{~mm}$, which was relatively abundant. The annual average temperature in this area was $17.5^{\circ} \mathrm{C} \sim$ $18.8^{\circ} \mathrm{C}$, the lowest temperature recorded was $-7.8^{\circ} \mathrm{C}$ and the highest temperature recorded was $39.8^{\circ} \mathrm{C}$. An automatic meteorological station was installed to collect temperature, soil moisture, precipitation, and relative humidity measurements every $15 \mathrm{~min}$ at the study site. According to the linear relationship between rainfall and temperature recorded by the automatic weather station, A Bagnouls-Gaussen bioclimatic diagram (Figure 2) was made to evaluate the drought situation under natural conditions in the study area. The method considered that when the total monthly precipitation was less than twice the mean temperature in that month defined as arid. The results in Figure 2 show only six months with a soil water deficiency during the 34 study months (April 2013 to January 2016). Therefore, we considered that the study site without aridity could be used as a control group.

\section{Experimental Design and Sampling}

The sample plot was set up on a 30 slope in April 2013 (Field experiments were approved by the farmer Ping Xiu who had the ownership of the field), which had a total 42 P. massoniana individuals nearly 25 years old. On average, those similar P. massoniana individuals were 4.2 $\mathrm{cm}$ in diameter at breast height (DBH), $2.4 \mathrm{~m}$ in height and $8.5 \mathrm{~cm}$ in blade length. The sample plot were divided into four small plots $(20 \times 20 \mathrm{~m})$ (Urbina et al. 2015). In order to avoid the influence of slope on sampling, two small plots with $20 \mathrm{P}$. massoniana individuals (one uphill and one downhill) received $100 \%$ rainfall exclusion as drought plots, and the other two plots with 22 P. massoniana individuals in the natural environment did not receive any treatment served as control plots. In the drought group, a top rain reduction device was installed. Transparent tiles were fixed above the study plot, and all rainfall was intercepted above the whole canopy. The light transmittance of the wave pattern can reach $90 \%$. Because the device was built only above the top of the canopy, the air convection around was sufficient, and the temperature and humidity of the two group were consistent. At the same time, to ensure the rainfall could flow out of the isolation area, the wave tiles were parallel to the plots (Sardans et al. 2007; Sardans et al. 2013) . Then, a soil lateral water control device was built around the study site. According to the sampling of $P$. massoniana, it was found that the main root was $2 \mathrm{~m}$ deep and the lateral root was less than $80 \mathrm{~cm}$. Therefore, an $80 \mathrm{~cm}$ deep channel was dug around the study site, and aluminum plates were installed in the channel to avoid water infiltration. The control group maintained the natural state without any treatment. Finally, to prevent small animals from destroying the plots, the four plots were surrounded by wire to ensure that the test ran without interference. 
157

158

159

160

161

162

163

164

165

166

167

168

169

170

171

172

173

174

175

176

177

178

179

180

181

182

183

184

185

186

187

188

189

190

191

192

193

194

195

196

On August 18, 2013 (115 days after 100\% isolated rainfall), 3 P. massoniana individuals with relatively consistent height and diameter were randomly selected in the middle of 4 plots (total $n=12$ ). The dates of plant sampling were selected based on the major climatic factors of the study site. In the study period, leaves and branches were collected from each sample individual one a quarterly basis to measure trace elemental concentrations. The 11 sampling times were as follows: day 115 (2013.8.18, late summer), day 185 (2013.10.27, autumn), day 256 (2014.1.6 winter), day 332 (2014.3.23 spring), day 467 (2014.8.1, late summer), day 542 (2014.10.15, autumn), day 638 (2014.12.30, winter), day 738 (2015.4.9, spring), day 861 (2015.8.10, late summer), day 941 (2015.10.29, autumn) and day 1032 (2016.1.28, winter) (Anderson 1964).

To minimize the impact of diurnal variability, one branch with healthy leaves completely exposed to the sun was collected from the east、south、west、north directions in the middle and upper parts of the crown of the selected sample individual between 9:00 am and 11:00 am on the sampling day, and then the healthy leaves with lengths of $8.3 \sim 8.6 \mathrm{~cm}$ and the branches with diameters of $0.3 \sim 0.5 \mathrm{~cm}$ were selected to mix as one leaf sample and one branch sample, respectively. All samples were immediately stored in an ice box $\left(0-4^{\circ} \mathrm{C}\right)$ and brought back to the laboratory. First, the enzymatic activity of the sample was inhibited by microwave treatment at $800 \mathrm{~W}$ for $5 \mathrm{~min}$ and then the sample was dried in an oven at $65^{\circ} \mathrm{C}$ for $48 \mathrm{~h}$ to obtain a constant weight (Körner 2002). The samples were ball milled to a fine powder (Tissuelyser-24, CHN), which served to measure trace elements (Lin et al. 2020).

\section{Chemical analyses}

The concentrations of $\mathrm{Fe}, \mathrm{Cu}, \mathrm{Zn}, \mathrm{Cd}, \mathrm{Ni}$, and $\mathrm{Cr}$ were measured in leaves and branches using ICP-MS (Mass Spectroscopy with Inductively Couple Plasma, Thermo iCAP Q, USA). Before ICP-MS analyses, the samples was acid digested with an $\mathrm{HNO}_{3} \sim \mathrm{H}_{2} \mathrm{O}_{2}$ mixed acid system (Martínez-Fernández et al. 2015). First, $100 \mathrm{mg}$ of dried leaf and branch powders were accurately weighed and placed in a $50 \mathrm{ml}$ disposable polyperfluoroethylene (FEP) digestion tube (Eid \& Shaltout 2014). FEP tubes with $8 \mathrm{ml}$ of nitric acid (65\%) (Merck GR, Germany) and $2 \mathrm{ml}$ of $\mathrm{H}_{2} \mathrm{O}_{2}(30 \%)$ were incubated overnight. The next morning, the tubes were shaking gently and placed in a graphite furnace for digestion. Gradient heating was used for the acid digestion (first step: heated to $80^{\circ} \mathrm{C}$ for $10 \mathrm{~min}$; second step: $100^{\circ} \mathrm{C}$ for $30 \mathrm{~min}$; and third step: raised to $110^{\circ} \mathrm{C}$ and maintained until the white smoke was exhausted; last, the obtained solution was concentrated to approximately 1 to $2 \mathrm{ml}$ ). FEP tubes were taken out and cooled at normal atmospheric temperature, and then Milli-Q water was added to a constant volume. Finally, the sample solutions filtered by $0.45 \mu \mathrm{m}$ microporous membranes were stored in the refrigerator for detection (Malea \& Kevrekidis 2013). Plant trace element concentrations were shown in mg. $\mathrm{kg}^{-1}$ by dry weight.

\section{Method for measuring water stress}

To verify the effectiveness of isolated rainfall, the leaf water potential values $(\Psi \mathrm{d})$ of $P$. massoniana in different treatment groups were determined within one year after the beginning of isolated rainfall. The six target individuals (three from the uphill plot and three from the downhill plot) were chosen from each treatment, then south branches with health leaves from the upper 
197

198

199

200

201

202

203

204

205

206

207

208

209

210

211

212

213

214

215

216

217

218

219

220

221

222

223

224

225

226

227

228

229

230

231

232

233

234

235

236

crown of which were collected at 6:00 am on a clear day every month. They were placed immediately in a cold closet, and then taken to the laboratory to determine the leaf water potential by a WP4 dew-point potential meter (Decagon Device, Pullman, WA, USA) (Klein et al. 2010).

The soil moisture contents at $20 \mathrm{~cm}$ and $80 \mathrm{~cm}$ from each treatment were determined automatically at intervals of $15 \mathrm{~min}$ using Time Domain Reflectometry (Trime-T3 Moisture Meter, IMKO, GER) (Sardans et al. 2013).

\section{Statistical Analyses}

SPSS 19.0 (SPSS Inc. Chicago, USA) for Windows statistical software was used for all results. Samples from each treatment were replicated for six times. Statistical analyses were applied to obtain a distinctive view of the influence of treatment and time on the data variability. We used a one-way ANOVA to detect the effects of different seasons or treatments on the concentrations of trace elements. Repeated measures analysis of variance (ANOVA) were used to study the effects of season and treatment on the amount of trace elements. The correlation analysis was used to compare the relationships among different trace elements. Principal component analysis (PCA) was used to provide scores for observations (samples per treatment and season) and variables (trace element concentrations), which could be interpreted together. Significance and high significance levels for all tests were set at $p<0.05$ and $p<0.01$.

\section{Results}

\section{The relationship between soil moisture content and leaf water potential during a 3-yr period}

Figure 3 shows the dynamic changes in soil moisture content between the control and drought treatments. From the beginning of the experiment (2013), the general trends of soil moisture content in $20 \mathrm{~cm}$ and $80 \mathrm{~cm}$ soil layers of the control group both showed a significant seasonal variation trend $(p<0.01)$ (Figure 3$)$. The valleys at $20 \mathrm{~cm}$ depth appeared in the control group on days 185 (27 October 2013, autumn) and 542 (25 October 2014, autumn), and the valleys at $80 \mathrm{~cm}$ depth appeared on days 185 (27 October 2013, autumn) and 638 (30 December 2014, winter). The 1032 days of $100 \%$ rainfall exclusion caused a mean reduction in the soil moisture contents at $20 \mathrm{~cm}$ (mean 10.69\%, CV: 4.69\%) and $80 \mathrm{~cm}$ (mean $17.31 \%, \mathrm{CV}: 10.44 \%$ ) compared to the soil moisture at $20 \mathrm{~cm}$ (mean $22.56 \%, \mathrm{CV}: 18.4 \%$ ) and $80 \mathrm{~cm}$ (mean $30.85 \%$, $\mathrm{CV}: 18.4 \%$ ) in the control group $(p<0.01)$, decreasing by $11.87 \%$ and $13.54 \%$, respectively (Figure 3). The observed effects of experimental drought from 2013 to 2016 resulted in mild drought conditions in the drought group (Hsiao \& Acevedo 1974; Zhang et al. 2015), which was likely because of the movement of soil capillary water caused by the moderate slope in the sample plot.

Leaf water potential is the most sensitive indicator of water deficit and drought resistance in plant organs. In the control group, the general trend of $\Psi \mathrm{d}$ showed obvious seasonal variation. However, $100 \%$ rainfall exclusion resulted in $\Psi \mathrm{d}$ weakening continuously in the drought group from April 2013 to March 2014. The mean value in the control group ( $\Psi \mathrm{d}:-2.80 \mathrm{MPa}, \mathrm{CV}$ : $10.00 \%$ ) was significantly higher than that in the drought group ( $\Psi \mathrm{d}:-3.73 \mathrm{MPa}, \mathrm{CV}: 7.78 \%$ )

Peer] reviewing PDF | (2020:05:49196:2:0:NEW 14 Aug 2020) 
237

238

239

240

241

242

243

244

245

246

247

248

249

250

251

252

253

254

255

256

257

258

259

260

261

262

263

264

265

266

267

268

269

270

271

272

273

274

275

$(p<0.05)$ (Figure 4). The decline in leaf water potential was an important indicator of plant water shortage, forming a large gradient between plant water potential and soil water potential, which was beneficial for plants to absorb water from soil and showed that P. massoniana in the drought group initiated the physiological mechanism that aims to use the lower leaf water potential to enhance the water absorption capacity of plant cells to improve their drought resistance.

\section{Characteristics of trace element concentrations in plant leaves and branches}

In our 3-yr experiment, the average concentrations of six trace elements in leaves of $P$. massoniana were in 100 to $500 \mathrm{mg} \cdot \mathrm{kg}^{-1}(\mathrm{Fe}), 10$ to $100 \mathrm{mg} \cdot \mathrm{kg}^{-1}(\mathrm{Zn})$, and less than $10 \mathrm{mg} \cdot \mathrm{kg}^{-1}$ $(\mathrm{Cu}, \mathrm{Ni}, \mathrm{Cr}, \mathrm{Cd})$ (Table 1). The average concentrations of elements from high to low are $\mathrm{Fe}>$ $\mathrm{Zn}>\mathrm{Cu}>\mathrm{Cr}>\mathrm{Ni}>\mathrm{Cd}$. In branches, the average concentrations of six trace elements were all significantly higher than those in leaves $(p<0.01)$, but except for the $\mathrm{Cu}$ concentration, which was different from the leaves at 10 to $100 \mathrm{mg} \cdot \mathrm{kg}^{-1}$, and the ranges and size sorting of other elements were the same. Compared with world terrestrial vascular plants, the average concentrations of $\mathrm{Fe}, \mathrm{Ni}$ and $\mathrm{Cr}$ in leaves and branches of $P$. massoniana were all significantly higher than those of global terrestrial vascular plants $(p<0.01)$, where Fe and Ni were nearly 2 times higher than the maximum, and $\mathrm{Cr}$ was 8 to 13 times higher than the maximum value. The average concentrations of $\mathrm{Zn}$ and $\mathrm{Cu}$ in branches were slightly higher than that of world terrestrial vascular plants, and the remaining elements fell in the normal range. The results showed that plants in this area were at a potential risk of being poisoned by heavy metals.

\section{Temporal variation in trace element concentrations}

An analysis of the seasonal dynamics of each trace element concentration behavior in the control group during these 3 years allowed us to distinguish three groups (Figure 5): (1) nutrientlike elements such as $\mathrm{Cu}, \mathrm{Zn}, \mathrm{Ni}$, and $\mathrm{Cd}$ had the highest trace element concentrations at the beginning of the growing season (spring), and then decreased in concentration from spring, to summer to autumn; notably, changes were more pluralistic from autumn to winter to spring; (2) the indifferent element Fe exhibited an increase in concentration from spring to summer and then a decrease in concentration to autumn, with the highest concentration occurring in summer; and (3) the accumulating element $\mathrm{Cr}$ showed an increase in concentration from spring-summer to autumn, but the situations in winters were different. However, this classification was slightly different from that revealed by statistical analysis.

Figure 6A presents the results of the unconstrained PCA. PC1 $\times$ PC2 revealed two groups of variables. One group comprised $\mathrm{Cu}, \mathrm{Zn}, \mathrm{Ni}, \mathrm{Cd}$ and $\mathrm{Cr}$. The elements of this group exhibited continuous change, that is, continuing to rise or decline during the growing season (Figure 5). The other group comprised Fe. This element first increased and then decreased. On PC1 $\times$ PC2, time scatter plots represented the position of each season category (Figure 6B). It appeared that summers from these 3-yr study periods were significantly distinguished from other seasons (Figure 6B). This difference could be linked to plant growth and photosynthetic processes during this active period. At the same time, spring, autumn and winter during these three years were concentrated together in Figure 6B. Therefore, we hypothesized that trace element 
276 concentrations in leaves of $P$. massoniana in the control group collected at different seasons

277 during the 3-yr study period could be analyzed in terms of seasonal variations.

278 As for branches, the $\mathrm{Cu}, \mathrm{Zn}, \mathrm{Ni}, \mathrm{Fe}, \mathrm{Cr}$, and $\mathrm{Cd}$ concentrations of the control group changed 279 more diversely. Although they had a certain seasonal dynamic, the annual peak appeared in 280 different seasons during the study period (Figure 7). An analysis of the branches revealed that all 281 trace elements did not have a completely consistent trend with leaves of the control group 282 (Figure 8). With branch trace element concentrations as variables in the control group, we could 283 not obtain useful information, and the PCA distinguished was messy (Figure 8).

284 Effect of drought on trace elements

285

286

287

288

289

290

291

292

293

294

295

296

297

298

299

300

301

302

303

304

305

306

307

308

309

310

311

312

313

314

315

The concentrations of trace elements in leaves and branches of the drought group showed increased concentrations of trace elements compared with those in the control group, such as $\mathrm{Cu}$ (0.51\%), Zn (9.13\%), Ni (1.23\%), Fe (67.8\%), and Cr (19.85\%) in leaves; $\mathrm{Cu}(6.99 \%), \mathrm{Zn}$ (14.11\%), $\mathrm{Fe}(2.16 \%)$, and $\mathrm{Cr}(23.11 \%)$ in branches and decreased $\mathrm{Cd}(-14.8 \%)$ in leaves and $\mathrm{Ni}$ $(-3.00 \%)$ and $\mathrm{Cd}(-14.5 \%)$ in branches. However, drought general resulted in no significant concentration differences under water stress conditions, except in the case of leaf $\mathrm{Fe}(p<0.05)$, leaf $\mathrm{Cr}(p<0.05)$ and branch $\mathrm{Cr}(p<0.05)$. The leaf Fe concentration exhibited a clear upward trend from day 332 to day 1032, while the leaf $\mathrm{Cr}$ concentration increased except on days 115 and 332, and the branch $\mathrm{Cr}$ concentration decreased except on days 332 and 941 (Figure 5,7). Figure 9 presents the results of the unconstrained PCA and shows the dates of the trace element concentrations in the leaves collected from different treatments in the 3-yr study period. The PC1 $\times$ PC2 treatment scatter-plot represents the position of each sample time in the control and drought groups. It appeared that most sample times in the drought group could be significantly distinguished from sample times in the control group. Similar processes seemed to occur in the branch tissues, and it was difficult to distinguish the sample times in the different treatments, but the 8 groups of different treatments were clustered together in the same sampling time (Figure 10). As a result, trace element concentrations in leaves of $P$. massoniana could be analyzed in terms of treatment variation.

\section{Discussion}

\section{Seasonal dynamics of trace element concentrations in $P$. massoniana in the control group}

The seasonal patterns of leaf nutrient-like elements such as $\mathrm{Cu}, \mathrm{Zn}, \mathrm{Ni}$, and $\mathrm{Cd}$ concentrations were similar and in agreement with the data for other plants from various environments (Hagemeyer JA 1992; Viers et al. 2012). Leaf Cu, Zn, Ni and Cd concentrations in the control group all showed the highest in the early growth season, indicating a strong metabolic processes (high photosynthetic activity, protein synthesis energy requirements) (Arneth et al. 1996). Notably, from winter to spring, $\mathrm{Cu}, \mathrm{Zn}, \mathrm{Ni}$ and $\mathrm{Cd}$ increased. However, during these periods, the soil temperature was low and the roots could not absorb nutrients from soil (Prokushkin et al. 2010). Therefore, these elements probably came from the pool of elements that plant preserved in the early stage of their growth. These elements could be mobilized to the phloem before old leaf senescence and redistributed through xylem the following year to younger tissues that needs to grow (Viers et al. 2012). Then, the decrease in leaf $\mathrm{Cu}, \mathrm{Zn}, \mathrm{Ni}$ and 
$316 \mathrm{Cd}$ concentrations of the control group in the middle and late growing seasons may be explained

317 by two processes: (1) nutrients accumulated by mature leaves were absorbed into active growing 318 areas (e.g., fine roots and shoots) or reproductive organs; and (2) nutrients were dilution by 319 carbon accumulation. The indifferent element Fe exhibited an increase in concentration from

320

321

322

323

324

325

326

327

328

329

330

331

332

333

334

335

336

337

338

339

340

341

342

343

344

345

346

347

348

349

350

351

352

353

354

355 spring to summer and then a decrease in concentration to autumn. The highest concentration appeared in the most vigorous summer with the strongest photosynthesis. It is believed that many enzymes involved in chlorophyll biosynthesis and respiratory metabolism are Fe compounds; thus, the stronger photosynthesis was, the higher the Fe concentration. The accumulating element Cr showed an increase in concentration from spring-summer to autumn, but the situation in winter was different.

\section{Effects of drought on trace element concentrations in $P$. massoniana in the drought group}

The $3-\mathrm{yr}$ of $100 \%$ rainfall exclusion, which provoked an average reduction of $11.87 \%$ (20 $\mathrm{cm})$ and $13.54 \%(80 \mathrm{~cm})$ in the relative moisture of the soil, had some effects on trace element concentrations in the drought group. In general, water stress increased most trace elements in leaves and branches, but by statistical analysis, there were no significant concentration differences under water stress conditions except for increased leaf $\mathrm{Fe}$ and leaf and branch $\mathrm{Cr}$ concentrations significantly $(p<0.05)$. Most studies found that the increase in trace elements in the stress environment were related to the general enhancement of resource capture in soil microbe activity (Sardans et al. 2006), and photosynthesis capacity (Llorens 2004). Then enhancement of the photosynthetic capacity and the demand for resources of young leaves made the soluble organic matter migrate before senescence by the, which was the reason for the retention of trace elements in the aboveground biomass and mainly in leaves under stress conditions (Sardans et al. 2007). In addition, the increase in trace element concentrations in the stress environment was related to the plant showing high plant uptake, retranslocation and production capacities. Therefore, we believed that in our study site, $P$. massoniana individual as a pioneer specie of the red soil erosion area in Changting County, were able to survive easily in adverse situations due to their strong regulatory capacity. For example, P. massoniana, as a resprouting species, has a superficial root system, and under the water stress conditions, it could change the root structure to develop a deep root system to obtain water from the deepest layers where the impacts of drought and pollution were reduced (Sardans et al. 2007). Even it seemed to have a dural root system (Filella \& Peñuelas 2003), where the deeper roots supplied moisture to the superficial roots, thereby allowing the plant to remain active and able to exploit water resources in different soil layers. In our study, the significant enhancement of the leaf $\mathrm{Fe}$ concentration and leaf and branch $\mathrm{Cr}$ concentrations in the drought group seemed to be related to an increase in the internal mobilization of resources due to the increases in photosynthetic and metabolic capacities (Llorens 2004). Fe is involved in the production of chlorophyll pigment molecules. It is a component of many enzymes associated with energy transfer, nitrogen reduction and fixation and lignin formation (Ahanger et al. 2016). A greater leaf Fe concentration could be associated with a higher quantity of chlorophyll, which would accelerate photosynthesis in P. massoniana (Sánchez-Rodríguez et al. 2010). However, less is known about 
356

357

358

359

360

361

362

363

364

365

366

367

368

369

370

371

372

373

374

375

376

377

378

379

380

381

382

383

384

385

386

387

388

389

390

391

392

393

394

395

396

397

398

399

400

why drought could increase the $\mathrm{Cr}$ concentration in leaves and branches, which even enhances potential toxicity.

\section{Conclusions}

The distribution of trace elements in plants could effectively reflect ecological adaptation strategies. The results showed that the concentrations of $\mathrm{Fe}, \mathrm{Cu}, \mathrm{Zn}, \mathrm{Cd}, \mathrm{Ni}$, and $\mathrm{Cr}$ in leaves and branches had an obvious seasonal variation tendency in the control group, which could be divided into three types according to seasonal pattern: the first type was leaf nutrient-like elements such as $\mathrm{Cu}, \mathrm{Zn}, \mathrm{Ni}$, and $\mathrm{Cd}$, which decreased continuously with the growing season; the second type was the indifferent element $\mathrm{Fe}$, which exhibited an increase in concentration from spring to summer and then a decrease from summer to autumn, and the highest concentration appeared in the most vigorous summer; the third type was the accumulating element $\mathrm{Cr}$, which showed an increase in concentration from spring-summer to autumn. The concentrations of trace elements in the control group were significantly higher than those in leaves. The concentrations of trace elements in the leaves and branches of P. massoniana showed no significant differences with mild drought stress, except for the leaf $\mathrm{Fe}$ and $\mathrm{Cr}$ concentrations and the branch $\mathrm{Cr}$ concentration, which were significantly increased $(p<0.05)$. The increases in $\mathrm{Fe}$ and $\mathrm{Cr}$ concentrations were the result of self-selection by $P$. massoniana under mild drought stress.

\section{Acknowledgements}

We thank Xiao-hui Zhong and Wan-yv Lin for their assistance in the field and lab.

\section{References}

Ahanger MA, Morad-Talab N, Abd-Allah EF, Ahmad P, and Hajiboland R. 2016. Plant growth under drought stress.649-668.

Anderson JM, and Proctor J. 1990. Mineral Nutrients in Tropical Forest and Savanna Ecosystems. The Journal of Ecology 78:1155.

Anderson TW. 1964. Some Approaches to the Statistical Analysis of Time Series. Australian Journal of Statistics 6:1-11.

Arneth A, Kelliher FM, Bauer G, Hollinger DY, Byers JN, Hunt JE, McSeveny TM, Ziegler W, Vygodskaya NN, Milukova I, Sogachov A, Varlagin A, and Schulze ED. 1996. Environmental regulation of xylem sap flow and total conductance of Larix gmelinii trees in eastern Siberia. Tree Physiology 16:247-255.

Baycu G, Tolunay D, Özden H, and Günebakan S. 2006. Ecophysiological and seasonal variations in $\mathrm{Cd}, \mathrm{Pb}, \mathrm{Zn}$, and $\mathrm{Ni}$ concentrations in the leaves of urban deciduous trees in Istanbul. Environmental Pollution 143:545-554.

Blasco B, Graham NS, and Broadley MR. 2015. Antioxidant response and carboxylate metabolism in Brassica rapa exposed to different external $\mathrm{Zn}, \mathrm{Ca}$, and $\mathrm{Mg}$ supply. Journal of Plant Physiology 176:16-24.

Eid EM, and Shaltout KH. 2014. Monthly variations of trace elements accumulation and distribution in above- and below-ground biomass of Phragmites australis (Cav.) Trin. ex Steudel in Lake Burullus (Egypt): A biomonitoring application. Ecological Engineering 73:17-25.

Elser JJ, Acharya K, Kyle M, Cotner J, Makino W, Markow T, Watts T, Hobbie S, Fagan W, Schade J, Hood J, and Sterner RW. 2003. Growth rate-stoichiometry couplings in diverse biota. Ecology Letters 6:936-943.

Elser JJ, Fagan WF, Kerkhoff AJ, Swenson NG, and Enquist BJ. 2010. Biological stoichiometry

Peer) reviewing PDF | (2020:05:49196:2:0:NEW 14 Aug 2020) 
401

402

403

404

405

406

407

408

409

410

411

412

413

414

415

416

417

418

419

420

421

422

423

424

425

426

427

428

429

430

431

432

433

434

435

436

437

438

439

440

441

442

443

444

445

446

447

448

449

450

451 of plant production: metabolism, scaling and ecological response to global change. New Phytologist 186:593-608.

Etienne P, Diquelou S, Prudent M, Salon C, Maillard A, and Ourry A. 2018. Macro and Micronutrient Storage in Plants and Their Remobilization When Facing Scarcity: The Case of Drought. Agriculture 8:14.

Filella I, and Peñuelas J. 2003. Partitioning of water and nitrogen in co-occurring Mediterranean woody shrub species of different evolutionary history. Oecologia 137:51-61.

Grubb PJ, Turner IM, and Burslem DFRP. 2009. Mineral nutrient status of coastal hill dipterocarp forest and adinandra belukar in Singapore: analysis of soil, leaves and litter. Journal of Tropical Ecology 10:559-577.

Güsewell S, Bailey KM, Roem WJ, and Bedford BL. 2005. Nutrient limitation and botanical diversity in wetlands: can fertilisation raise species richness? Oikos 109:71-80.

Hagemeyer JA LM, Breckle SW. 1992. Are there seasonal variations of trace element concentrations (Cd, $\mathrm{Pb}, \mathrm{Zn}$ ) in wood of Fagus trees in Germany? Vegetation 101:55-63.

Han W, Fang J, Guo D, and Zhang Y. 2005. Leaf nitrogen and phosphorus stoichiometry across 753 terrestrial plant species in China. New Phytologist 168:377-385.

He M, Zhang K, Tan H, Hu R, Su J, Wang J, Huang L, Zhang Y, and Li X. 2015. Nutrient levels within leaves, stems, and roots of the xeric speciesReaumuria soongoricain relation to geographical, climatic, and soil conditions. Ecology and Evolution 5:1494-1503.

Hisano M, Searle EB, and Chen HYH. 2018. Biodiversity as a solution to mitigate climate change impacts on the functioning of forest ecosystems. Biological Reviews 93:439-456.

Hsiao TC, and Acevedo E. 1974. Plant responses to water deficits, water-use efficiency, and drought resistance. Agricultural Meteorology 14:59-84.

Kerkhoff AJ, Enquist BJ, Elser JJ, and Fagan WF. 2005. Plant allometry, stoichiometry and the temperature-dependence of primary productivity. Global Ecology and Biogeography 14:585-598.

Klein VA, Baseggio M, Madalosso T, and Marcolin CD. 2010. Textura do solo e a estimativa do teor de água no ponto de murcha permanente com psicrômetro. Ciência Rural 40:15501556.

Körner GHMPC. 2002. Altitudinal increase of mobile carbon pools in Pinus cembra suggests sink limitation of growth at the Swiss treeline. Oikos 98:361-374.

Lacointe A, Kajji A, Daudet F-A, Archer P, Frossard J-S, Saint-Joanis B, and Vandame M. 1993. Mobilization of carbon reserves in young walnut trees. Acta Botanica Gallica 140:435441.

Lin T, Fang X, Lai $Y$, Zheng $H$, and Zhu J. 2020. Shifts in Leaf and Branch Elemental Compositions of Pinus massoniana (Lamb.) Following Three-Year Rainfall Exclusion. Forests 11:113.

Llorens L. 2004. Contrasting Growth Changes in Two Dominant Species of a Mediterranean Shrubland Submitted to Experimental Drought and Warming. Annals of Botany 94:843853.

Mahdavi S KM, Fallahi E, Shokrpour, Tabrizi L. 2016. Water stress nano silica and digoxin effects on minerals chlorophyll index and growth in ryegras. International Journal of Plant Prouduction 10:251-264.

Malea P, and Kevrekidis T. 2013. Trace element (Al, As, B, Ba, Cr, Mo, Ni, Se, Sr, TI, U and V) distribution and seasonality in compartments of the seagrass Cymodocea nodosa. Science of The Total Environment 463-464:611-623.

Martínez-Fernández D, Vítková M, Bernal MP, and Komárek M. 2015. Effects of Nanomaghemite on Trace Element Accumulation and Drought Response of Helianthus annuus L. in a Contaminated Mine Soil. Water, Air, \& Soil Pollution 226.

Paiva CL, Queiroz VAV, Simeone MLF, Schaffert RE, de Oliveira AC, and da Silva CS. 2017. Mineral content of sorghum genotypes and the influence of water stress. Food

Peer) reviewing PDF | (2020:05:49196:2:0:NEW 14 Aug 2020) 
452

453

454

455

456

457

458

459

460

461

462

463

464

465

466

467

468

469

470

471

472

473

474

475

476

477

478

479

480

481

482

483

484

485

486

487

488

489

490

491

492

493

494

495

496

497

498

499

500

501

502

Chemistry 214:400-405.

Peñuelas J, Marino G, Llusia J, Morfopoulos C, Farré-Armengol G, and Filella I. 2013. Photochemical reflectance index as an indirect estimator of foliar isoprenoid emissions at the ecosystem level. Nature Communications 4.

Peñuelas JFI. 2002. Metal pollution in Spanish terrestrial ecosystems during the twentieth century. Chemosphere 46:501-505.

Philippot L, Raaijmakers JM, Lemanceau P, and van der Putten WH. 2013. Going back to the roots: the microbial ecology of the rhizosphere. Nature Reviews Microbiology 11:789799.

Phipps DA. 1981. Chemistry and Biochemistry of Trace Metals in Biological Systems.1-54.

Prokushkin SG, Bugaenko TN, Prokushkin AS, and Shikunov VG. 2010. Succession-driven transformation of plant and soil cover on solifluction sites in the permafrost zone of Central Evenkia. Biology Bulletin 37:80-88.

$\mathrm{R}$ Hajiboland. 2012. Effect of Micronutrient Deficiencies on Plant Stress. In: Abiotic stress responses in plants. Springer:281-230.

Roem WJ, and Berendse F. 2000. Soil acidity and nutrient supply ratio as possible factors determining changes in plant species diversity in grassland and heathland communities. Biological Conservation 92:151-161.

Sánchez-Rodríguez E, del Mar Rubio-Wilhelmi M, Cervilla LM, Blasco B, Rios JJ, Leyva R, Romero L, and Ruiz JM. 2010. Study of the ionome and uptake fluxes in cherry tomato plants under moderate water stress conditions. Plant and Soil 335:339-347.

Sardans J, and Peñuelas J. 2012. The Role of Plants in the Effects of Global Change on Nutrient Availability and Stoichiometry in the Plant-Soil System. Plant Physiology 160:1741-1761.

Sardans J, and Peñuelas J. 2007. Drought changes phosphorus and potassium accumulation patterns in an evergreen Mediterranean forest. Functional Ecology 21:191-201.

Sardans J, Peñuelas J, and Estiarte M. 2006. Warming and drought alter soil phosphatase activity and soil $P$ availability in a Mediterranean shrubland. Plant and Soil 289:227-238.

Sardans J, Peñuelas J, and Ogaya R. 2007. Drought's impact on Ca, Fe, Mg, Mo and S concentration and accumulation patterns in the plants and soil of a Mediterranean evergreen Quercus ilex forest. Biogeochemistry 87:49-69.

Sardans J, Peñuelas J, and Rivas-Ubach A. 2011. Ecological metabolomics: overview of current developments and future challenges. Chemoecology 21:191-225.

Sardans J, Rivas-Ubach A, Estiarte M, Ogaya R, and Peñuelas J. 2013. Field-simulated droughts affect elemental leaf stoichiometry in Mediterranean forests and shrublands. Acta Oecologica 50:20-31.

Urbina I, Sardans J, Beierkuhnlein C, Jentsch A, Backhaus S, Grant K, Kreyling J, and Peñuelas J. 2015. Shifts in the elemental composition of plants during a very severe drought. Environmental and Experimental Botany 111:63-73.

Van leperen W. 2016. Plant growth control by light spectrum: fact or fiction? Acta Horticulturae:19-24.

Viers J, Prokushkin AS, Pokrovsky OS, Auda Y, Kirdyanov AV, Beaulieu E, Zouiten C, Oliva P, and Dupré B. 2012. Seasonal and spatial variability of elemental concentrations in boreal forest larch foliage of Central Siberia on continuous permafrost. Biogeochemistry 113:435-449.

Wang M, Zheng Q, Shen Q, and Guo S. 2013. The Critical Role of Potassium in Plant Stress Response. International Journal of Molecular Sciences 14:7370-7390.

Waraich EA AR, Saifullah, Ashraf MY, Ehsanullah. 2011. Role of mineral nutrition in alleviation of drought stress in plants. Australian Journal of Crop Science 5:764-777.

Woods HA, Makino W, Cotner JB, Hobbie SE, Harrison JF, Acharya K, and Elser JJ. 2003. Temperature and the chemical composition of poikilothermic organisms. Functional

Peer] reviewing PDF | (2020:05:49196:2:0:NEW 14 Aug 2020) 
503

504

505

506

507

508

509
Ecology 17:237-245.

Yruela I. 2009. Copper in plants: acquisition, transport and interactions. Functional Plant Biology 36:409.

Zhang T, Cao Y, Chen Y, and Liu G. 2015. Non-structural carbohydrate dynamics in Robinia pseudoacacia saplings under three levels of continuous drought stress. Trees 29:18371849. 
Figure 1

Map of the study area.

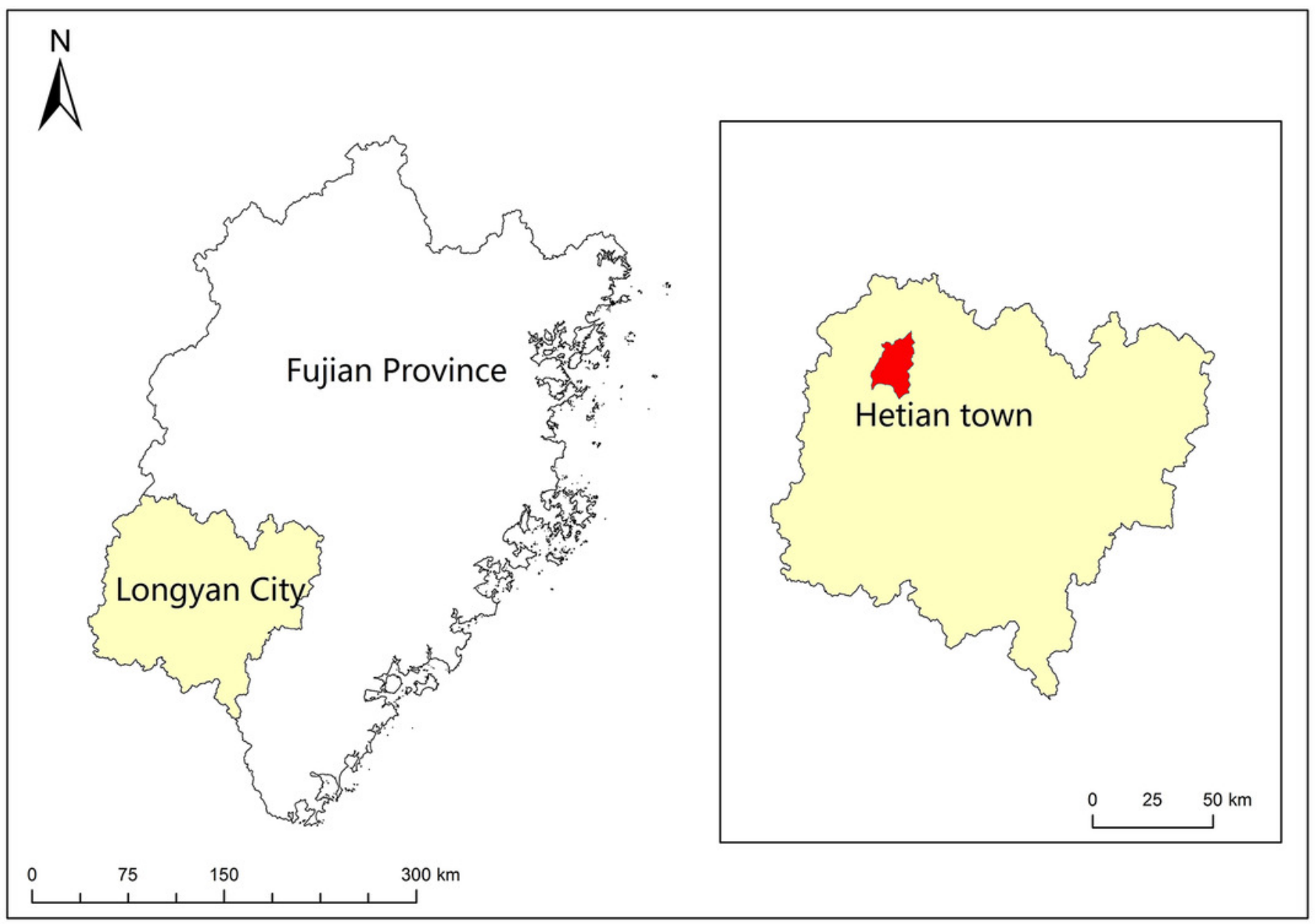


Figure 2

Bagnouls-Gaussen bioclimatic diagram.

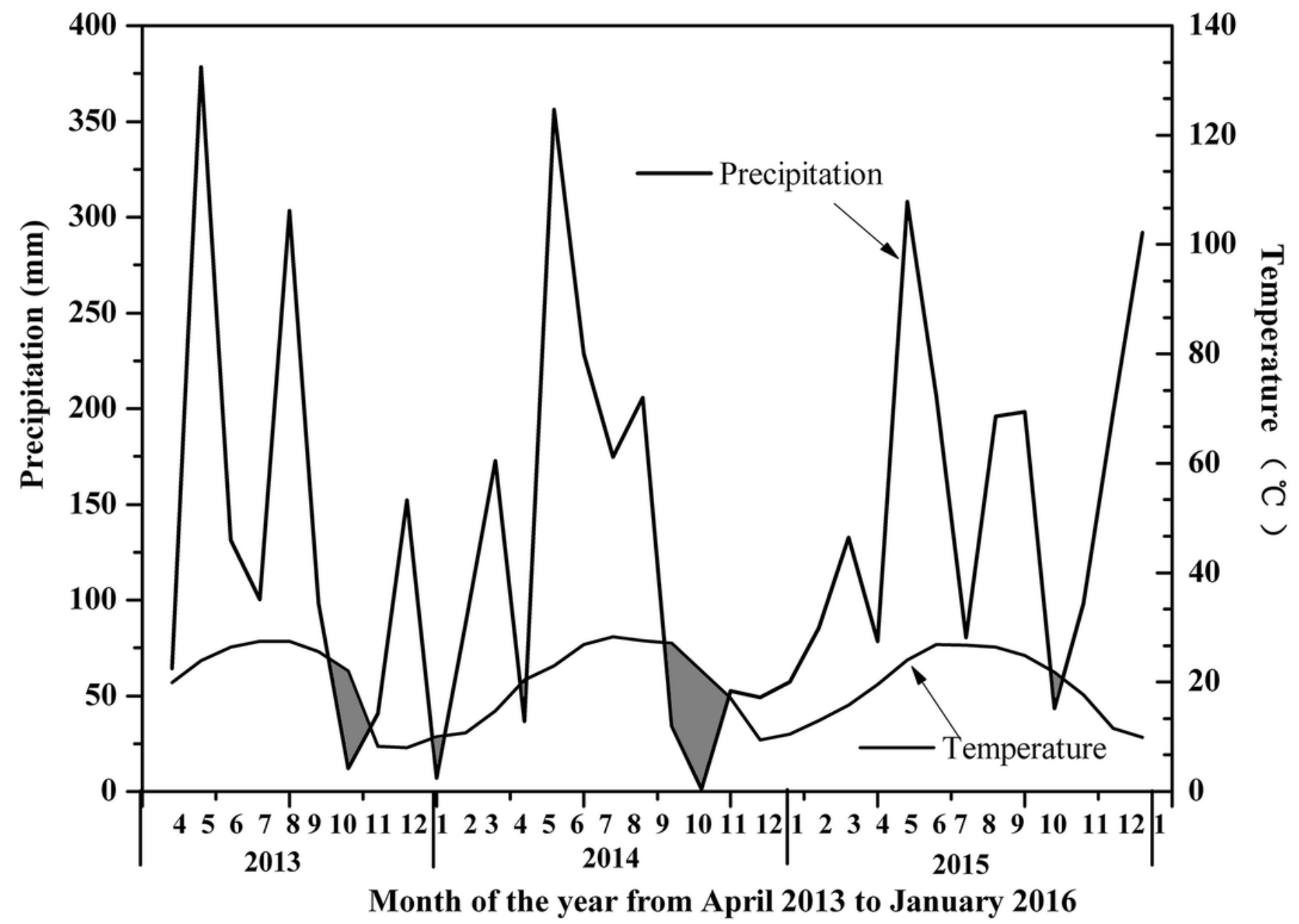


Figure 3

Seasonal variation of soil moisture content under different treatment in the study period.

(A) In the control group. (B) In the drought group.

S: spring; LS: late summer; A: autumn; W: winter.

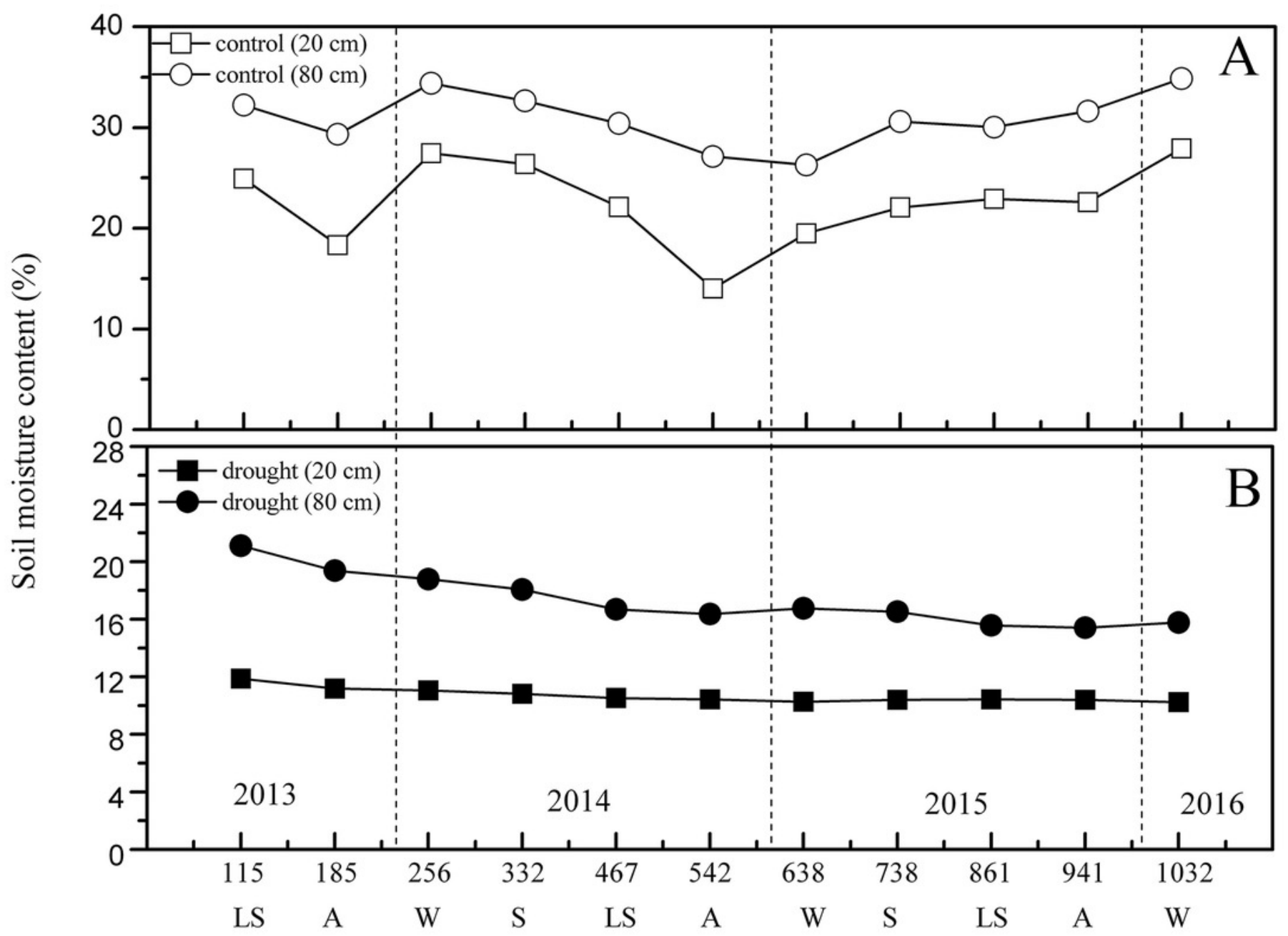


Figure 4

Monthly patterns of dawn leaf water potentials from April 2013 to March 2014.

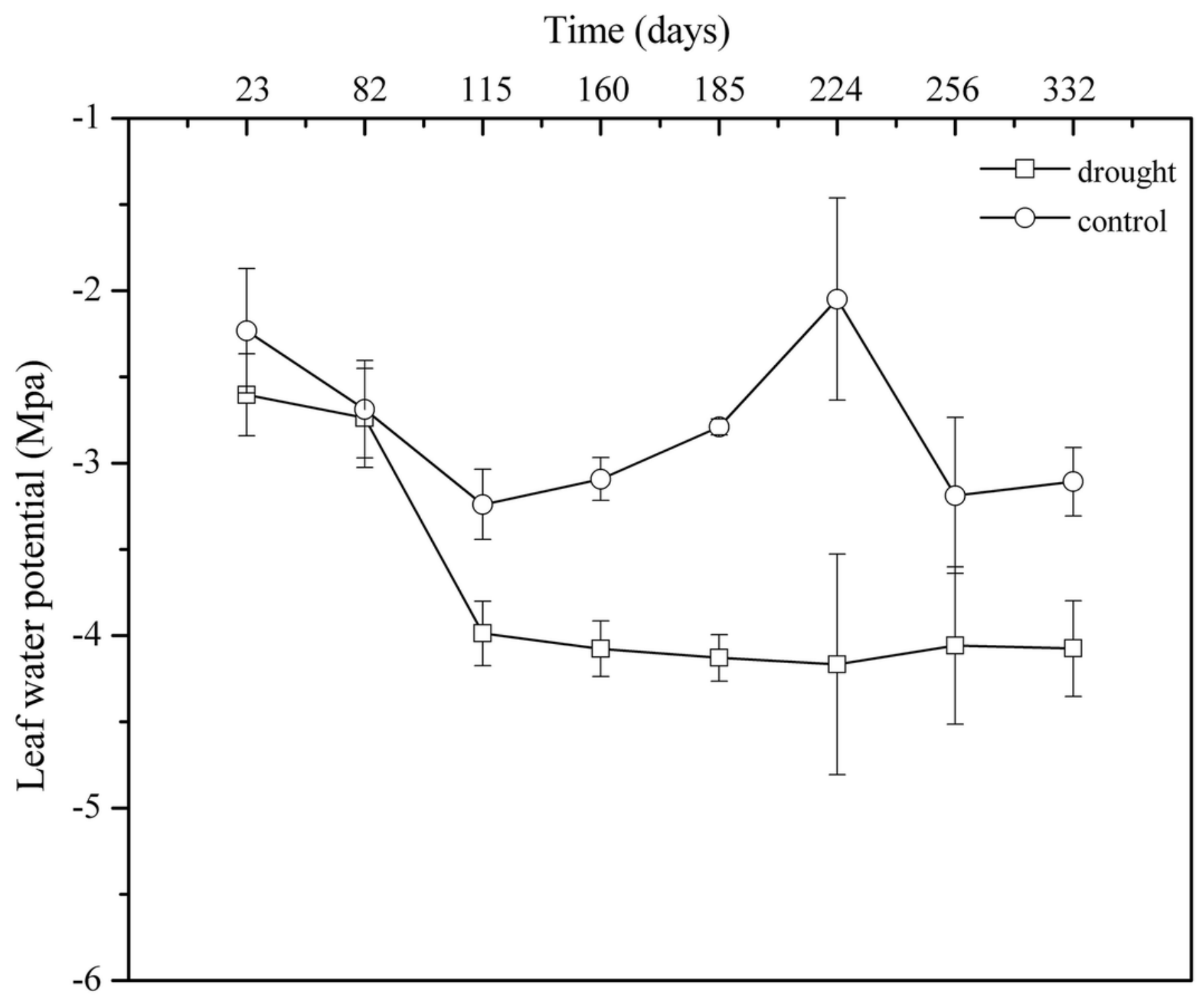


Figure 5

Leaf trace element concentrations of $\mathrm{Zn}, \mathrm{Cu}, \mathrm{Fe}, \mathrm{Ni}, \mathrm{Cr}, \mathrm{Cd}$ under different treatments (mean \pm SD).

(A) Zn. (B) Cu. (C) Fe. (D) Ni. (E) Cr. (F) Cd.

S: spring; Ls: late summer; A: autumn; W: winter.
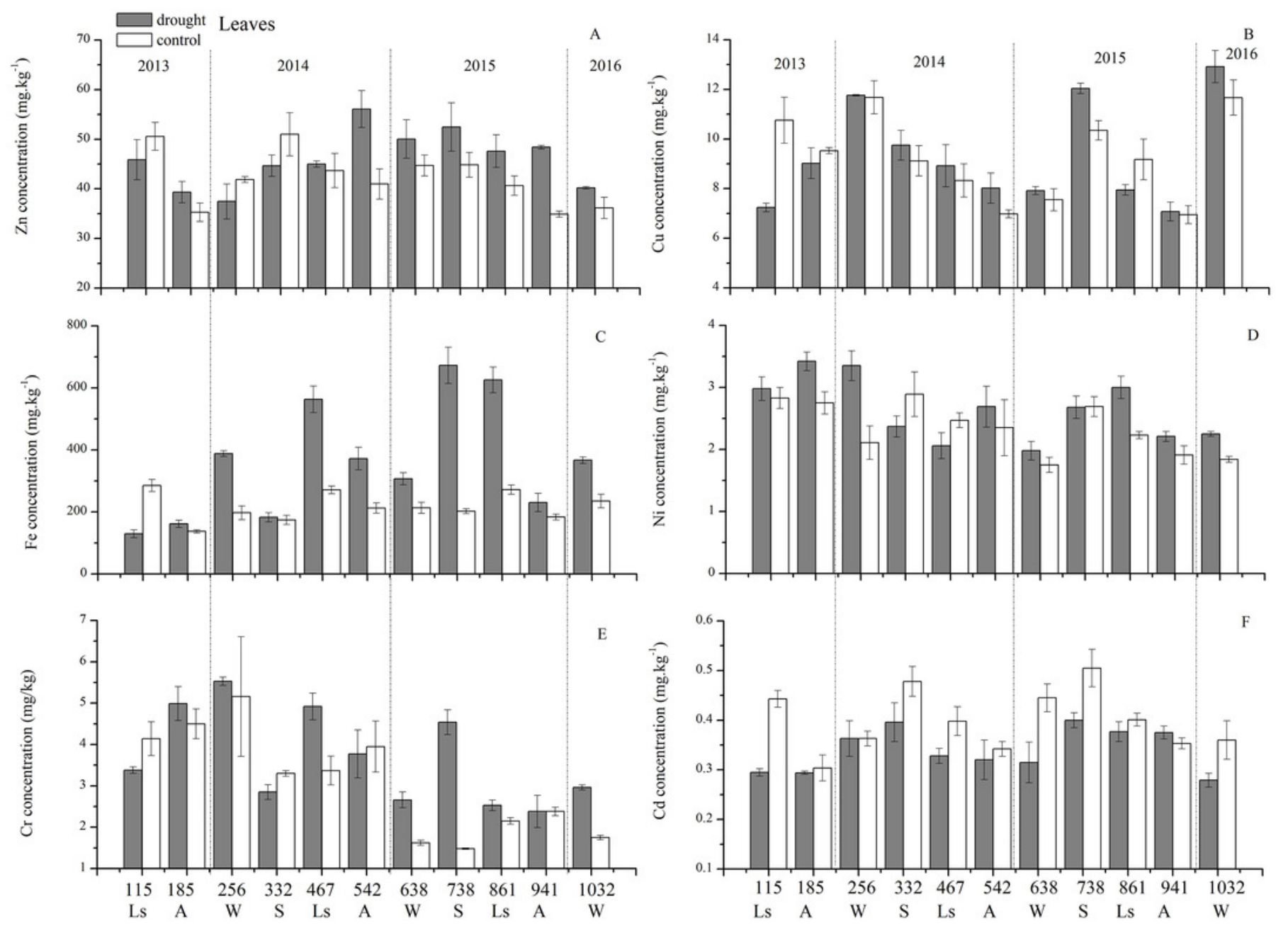
Figure 6

Principal component analyses of seasonal samples of $P$. massoniana leaves based on trace element concentrations in the control group.

(A) Correlation of variables. (B) Time scatter-plot of observations. C1032=day 1032 in the control group.

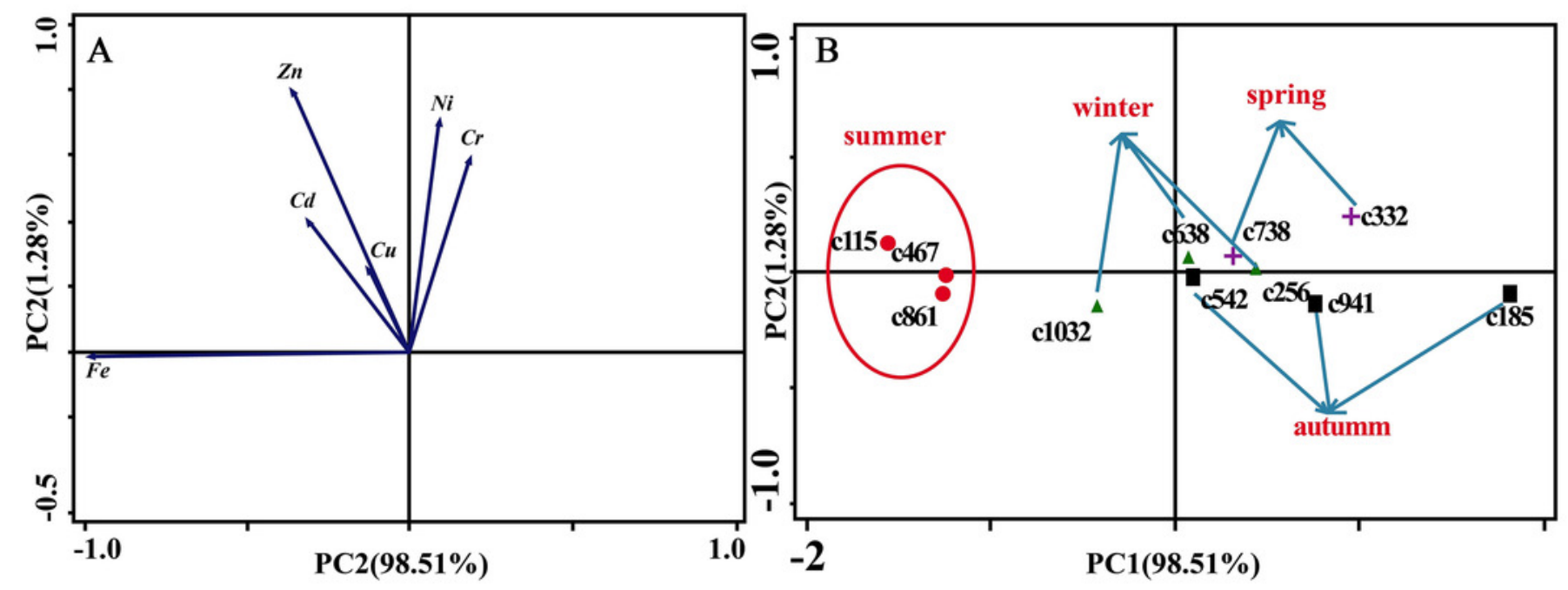




\section{Figure 7}

Branch trace element concentrations of $\mathrm{Zn}, \mathrm{Cu}, \mathrm{Fe}, \mathrm{Ni}, \mathrm{Cr}, \mathrm{Cd}$ under different treatments (mean \pm SD).

(A) Zn. (B) Cu. (C) Fe. (D) Ni. (E) Cr. (F) Cd.

S: spring; Ls: late summer; A: autumn; W: winter.
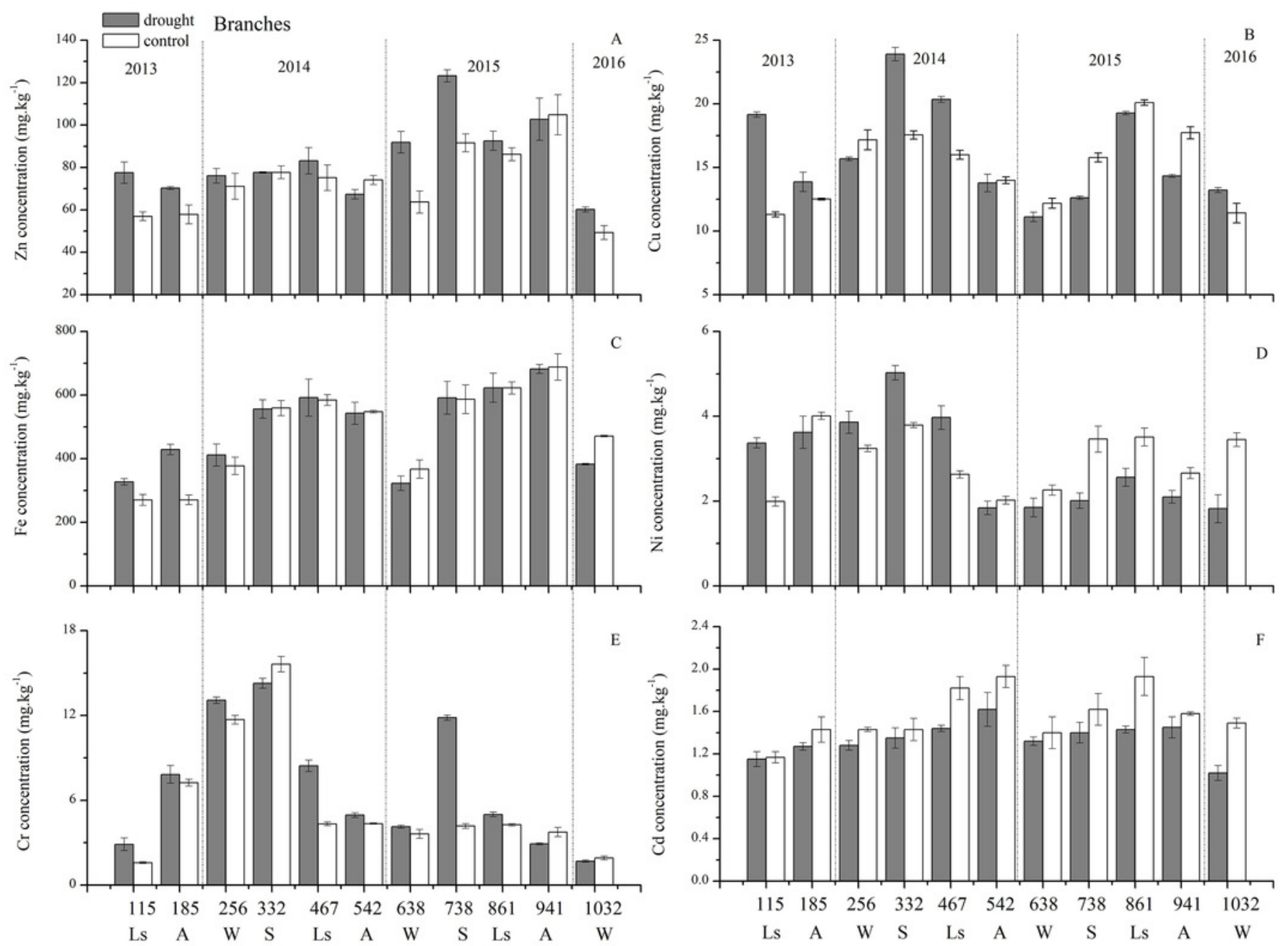
Figure 8

Principal component analyses of seasonal samples of $P$. massoniana branches based on trace element concentrations in the control group.

(A) Correlation of variables. (B) Time scatter-plot of observations. C1032=day 1032 in the control group.
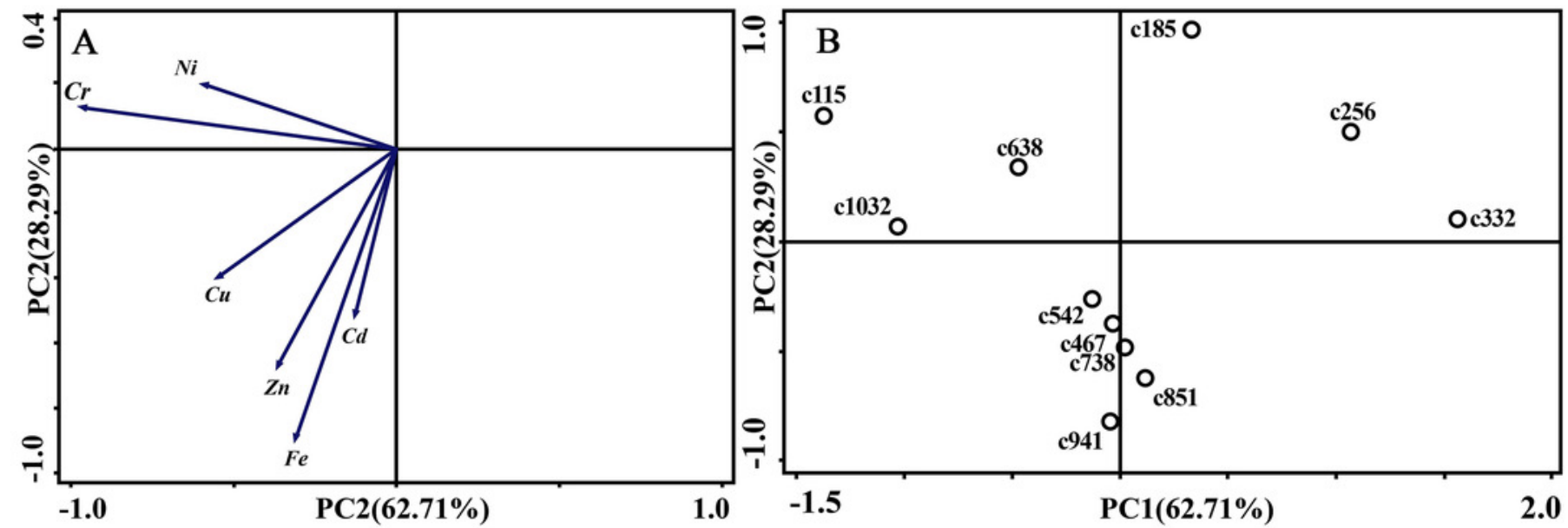
Figure 9

Principal component analyses of $P$. massoniana leaves based on trace element concentrations in different treatments.

PC1 $\times$ PC2 time scatter-plot of observations. c1032=day 1032 in the control group. d1032=day 1032 in the drought group.

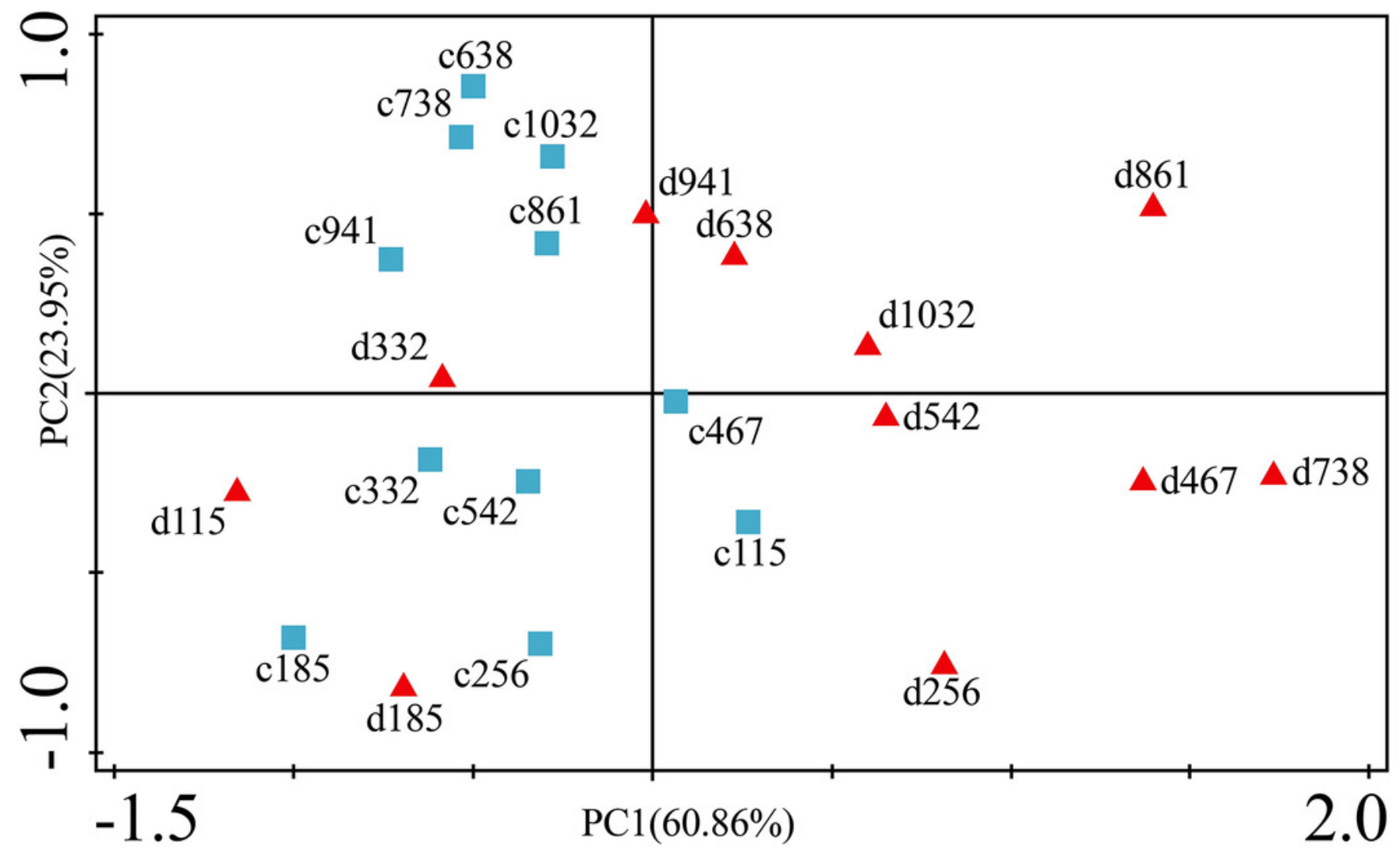


Figure 10

Principal component analyses of $P$. massoniana branches based on trace element concentrations in different treatments.

PC1 $\times$ PC2 time scatter-plot of observations. c1032=day 1032 in the control group. d1032=day 1032 in the drought group.

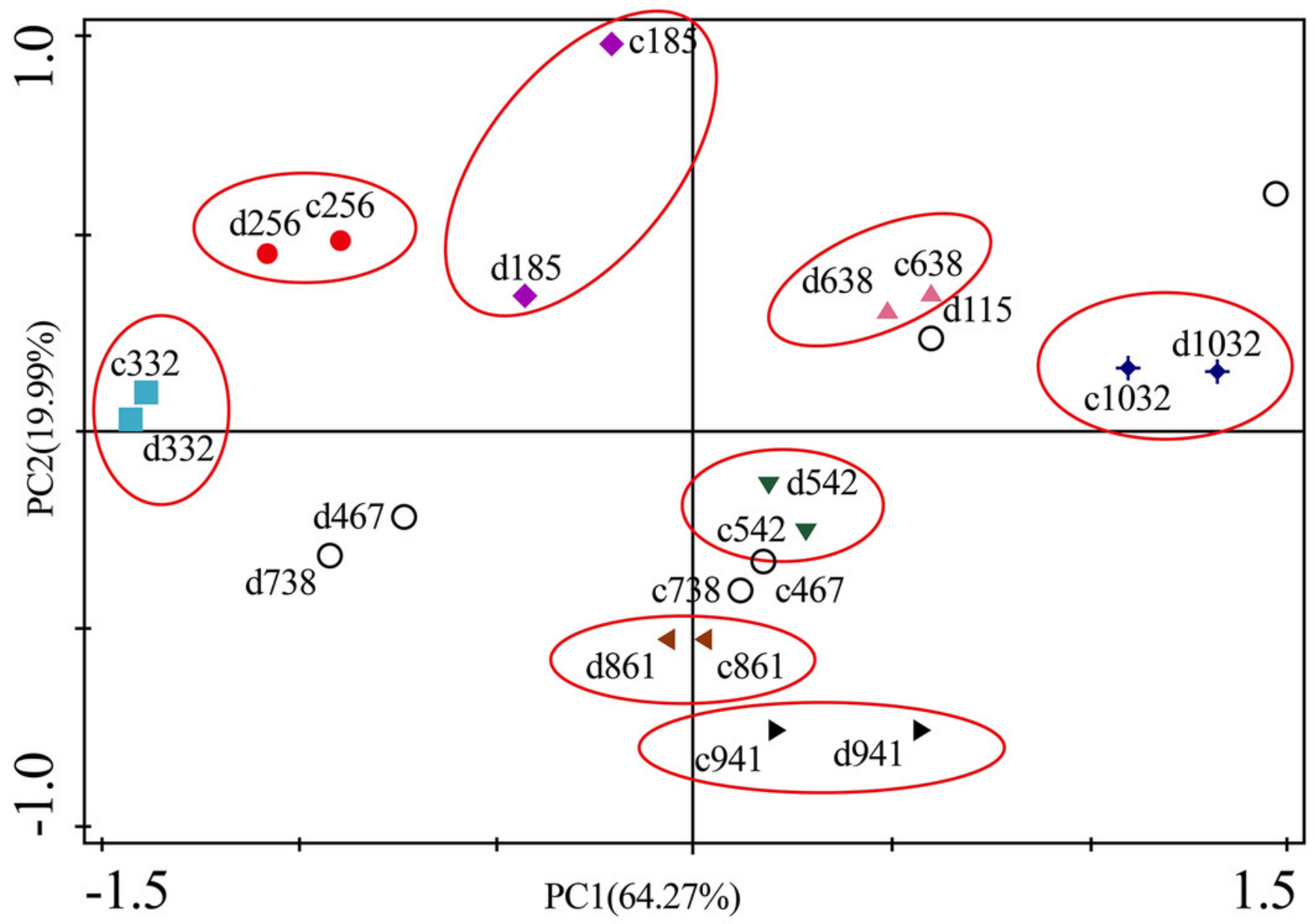




\section{Table $\mathbf{1}$ (on next page)}

The mean trace element concentrations of $P$. massoniana across the study period in the control and drought group mg. $\mathrm{kg}^{-1}$ 
1 Table 1 The mean trace element concentrations of $P$. massoniana across the study period in the control and 2 drought group mg.kg-1

\begin{tabular}{cccccc}
\hline \multirow{2}{*}{ Element } & \multicolumn{2}{c}{ In the control group } & \multicolumn{2}{c}{ In the drought group } & Range of terrestrial \\
& Leaf & Branch & Leaf & Branch & vascular plant \\
\hline $\mathrm{Fe}$ & $216.72 \pm 14.73$ & $485.93 \pm 21.94$ & $363.79 \pm 26.09$ & $496.41 \pm 28.97$ & $70 \sim 180$ \\
$\mathrm{Zn}$ & $42.25 \pm 2.30$ & $73.50 \pm 4.47$ & $46.11 \pm 2.63$ & $83.87 \pm 3.77$ & $34 \sim 68$ \\
$\mathrm{Cu}$ & $9.28 \pm 0.53$ & $15.07 \pm 0.38$ & $9.33 \pm 0.41$ & $16.12 \pm 0.32$ & $6 \sim 14$ \\
$\mathrm{Ni}$ & $2.35 \pm 0.19$ & $3.00 \pm 0.13$ & $2.64 \pm 0.17$ & $2.91 \pm 0.22$ & $0 \sim 1.4$ \\
$\mathrm{Cd}$ & $0.40 \pm 0.02$ & $1.57 \pm 0.10$ & $0.34 \pm 0.02$ & $1.34 \pm 0.07$ & $0.03 \sim 10$ \\
$\mathrm{Cr}$ & $3.07 \pm 0.32$ & $5.69 \pm 0.22$ & $3.68 \pm 0.25$ & $7.00 \pm 0.26$ & $0.1 \sim 0.5$ \\
\hline
\end{tabular}

3 